\section{THE ANTAGONIST IN THE TRICKSTER TALES OF TRANG QUYNH ${ }^{1}$}

\author{
Soratee Jaisa-ard ${ }^{2}$
}

\begin{abstract}
This article explores the antagonists from the tales of Trang Quynh, which are wellknown trickster tales throughout Vietnam. The main antagonists in Trang Quynh's series comprise those in the royal court, even the king himself, mandarins, rich landlords and even the mother Goddess at the village shrine. The tales of Trang Quynh can be interpreted as the farmers' way of alleviating their hardship, as an expression of their antagonism towards the ruling class and restrictive social rules. Meanwhile, Trang Quynh, the protagonist in the story, is regarded as the hero or the representative of the people. As a result, the study of Trang Quynh's antagonists will enhance our understanding of the social context, village culture and the conflict between social groups from the previous time in Vietnamese society.
\end{abstract}

\footnotetext{
${ }^{1}$ This article is part of the Ph.D. thesis "Vietnamese cultural identity and universal characteristics in the trickster tales of TRANG QUYNH”, Ph.D. Program in Department of Literature and Comparative Literature, Faculty of Arts, Chulalongkorn University.

${ }^{2}$ Lecturer, Department of Thai, Faculty of Humanities and Social Sciences, Khon Kaen University
}

\section{Trang Quynh tales series from the perspective of folklore}

Trang Quynh ${ }^{3}$ is a set of Vietnamese tales. It is recognized by Vietnamese folklore scholars as a humorous tale emphasizing amusement. In Vietnamese, it is known as truyện cười, truyện hài hước or truyện khôi hài which denotes a tale designed to entertain and amuse its audience. ${ }^{4}$ The story of Trang Quynh touches upon critical issues in society and social taboos. It also aims at both upper and lower class people and the protagonist of the story is enabled to do anything that he cannot do in real life. In the world of tales, the audience can find release from the oppression that they endure in everyday life. This topic will be discussed in more detail later in this article.

According to the Thai scholar, Prakong Nimmanahaeminda (1911: 20), a humorous tale is a "short story of noncomplicated structure and with one particular. The actor can be a human being or an animal. The climax of the story is an impossible circumstance." Another Thai scholar in Folklore, Siraporn Na Thalang (1994: 20) points out that an important role of the humorous tale is "to alternate oppression from social rules and regulations which cannot be spoken against or criticized in real life but can be in the world of tales." Because of its literary elements, The Trang Quynh series can be categorized as humorous tales.

\footnotetext{
${ }^{3}$ Trang (Trang) is the name prefix for an academic person, most of them possessed the first rank of Tiến sĩ (comparable to a present day doctoral degree).

${ }^{4}$ For more details, see Dinh Gia Khanh 2003. Van hoc dan gian Viet Nam. Nam Dinh: Giao duc.
} 
Stith Thomson (as referred to in Prakong Nimmannahaeminda's book, 1911: 20) proposes that there are 16 models of humorous stories as follows: cleverness, foolishness, winning a competition by deception, cunningly bargaining, discreetly playing tricks, deception aimed at sexual intercourse, harmful tricks, cunning in competition, imitation, incorrect blame, poor wife, laziness, deaf people, priests and boastfulness. According to Stith Thomson's models and the main character of the Trang Quynh series, it can be said that these are tales of cleverness, sagacity and tricks to survive. Some characters in the stories may like to ridicule, tease and joke. The characteristics of this series share similarities with the story of Sritanonchai, which is popular in Thailand, Tamenchia, in Cambodia, or some parts of Siangmiang, in Laos. ${ }^{5}$

It has been pointed out in some Vietnamese research that Trang Quynh is an important character in Vietnamese folklore. Some researchers have even speculated that this character is real. It is believed that Trang Quynh is Nguyễn Quúnh or Cèng Quúnh, who was born, in Thanh Hoa province, on the $26^{\text {th }}$ of the $10^{\text {th }}$ month in 1677. Trang Quynh was a smart child who was born into a peasant family. When he was 19 years old (1696), Quynh got the highest score in the official examination at the provincial level but he was subsequently unsuccessful though he attempted the examination numerous times in the capital city. However, at the age of

${ }^{5}$ For more information, see Vejchasartra, Kanyarat. 1998. Srithanonchai in South-east Asia. (ศรีธนญชัยในอุษาคเนย์) Bangkok:

Thammasat University Press.
41 (1718), he finally achieved "tien si", and worked as an official. According to historical documents, Quynh died on the $6^{\text {th }}$ of the $2^{\text {nd }}$ month of the year 1748. At that time, he was 78 years old. ${ }^{7}$

The Trang Quynh tale reflects Vietnamese society in the 18th century. At that time, the country was divided into two parts. The North was controlled by the Trinh while the South was under the Nguyen. While both families claimed to recognize the Le dynasty as the legitimate authority, they fought against each other. The civil war lasted for about fifty years until three brothers from the village of Tay Son, a province of Binh Dinh, rose up against the two families. (Huu Ngoc 1998: 618)

During the civil war, the peasants endured hardship and oppression. Most of the farmers did not have their own land and they were invariably oppressed and exploited by landlords. Apart from the problem of land, the peasant life was greatly affected by political conflicts, corruption, competition and jealousy among the high ranking mandarins and this led to peasant uprisings. The peasants' anxiety, fear and general attitude towards political and social circumstances are clearly demonstrated in the Trang Quynh

\footnotetext{
${ }^{6}$ Tiến si is the highest level of education. It was an examination to recruit officials or mandarins to work for the royal court. The examination normally consisted of Classical Chinese literature, Confucianism and poetry and article writing. There were thousands of applicants sitting the exam but only 100 were allowed to pass the test. Between the years 1529 and 1787 the test was held 102 times and only 1,136 applicants were successful.

${ }^{7}$ See Nguyen Duc Hien, Khao Luan and Bien Soan 2003. Nguyen Quynh Trang Quynh Truyen Trang Quynh. Da Nang: Giao Duc Press.
} 
stories. Due to the protracted period of civil war, the decline of the royal court and the mandarinate system, folk stories gained increasing popularity and began to become widespread among the peasantry.

The Trang Quynh series can be seen as the farmers' way of channelling their hardship and antagonism towards the ruling class as the result of restrictive social rules. The narrator of the Trang Quynh story is able freely to characterize the protagonist in the way he wants and even to make fun of the ruling class and such figures as mandarins, governors and Chinese lords. The farmers could not express their feelings openly in their real lives, but in the satirical folk stories they can reveal dissatisfaction with the differences between the rich and the poor and between the ruling class and the plight of the ruled. Most of the stories in the Trang Quynh series end with loss and the embarrassment of the ruling class. Audiences are very fond of these stories because they can feel the sense of justice throughout.

\section{Scope of Study}

The stories of Trang Quynh have been retold and reprinted many times in Vietnam. However, the discussion of the Trang Quynh stories in this article is based on the Vietnamese version in Nguyễn Trường's collection, Truyện cười dân gian Việt Nam Trạng Cười. (Nguyễn Trường 2004).

\section{Trang Quynh's Antagonists}

At the centre of Trang Quynh's trickster tales is the juxtaposition of opposites, namely Trang Quynh and his opponents such as religion and belief, royalty especially the Le family, the Trinh lords, Chinese officials and the local authories.
The oppositional stories tell us a great deal about the conflict between different classes in society and the peasants' antagonism towards the ruling class. The peasants and those from the lower classes can feel a sense of victory when Trang Quynh is able to trick the princes, mandarins or even the mother goddess. The following study will discuss in detail how the stories of Trang Quynh and his opponents play a vital role in provoking laughter among the audience.

R.S. Rattray (referring to Phongphan Manirat's book 1986: 100) Ashanti's folklore reveals that, in South African literature, there are many tales and satirical stories concerning doubt and disbelief in the omniscient in the form of gods, miracle workers, charms, potent spirits or powerful people. This disbelief sometimes appears in the form of dirty jokes. The audience enjoys listening to these stories. $\mathrm{He}$ then proposes that folklore helps people to release emotional pressure in order to alleviate social tension. This idea is supported by Siraporrn Thitathan Na ThaLang (2005: 362), who asserts that folklore can control the norms of behaviour and provide a social outlet. These views can be applied in the case of Trang Quynh to the extent that these series of tales functions as a social outlet. As demonstrated in the stories of Trang Quynh, the main character can mockingly attack any social rules or laws that people find oppressive. The antagonists in the trickster tales of Trang Quynh can be divided into 4 main categories: the mother goddess, the King, the Chinese and local Lords and rich people. 


\section{Trang Quynh and the mother goddess Bà Chúa Liễu}

In Vietnam's traditional society, shrines and temples were very influential not only because they were highly respected by local people but also due to the fact that they owned land and rented it to the people. The discussion here is related to the chapters on "Renting Land of Bà Chúa Liễu," and "Compensation For Mother Goddess Bà Chúa Liễu and Ba-Bò Ceremony." In the story, Bà Chúa Liễu is the mother goddess who looks after a holy shrine where people from many villages come to pay their respects and offer donations. This shrine owns many pieces of land and generates income by renting it to landless villagers. The holy shrine is also the place where people come to pray when they have problems. However, she is overcome by Trang Quynh's cleverness. The following passage shows how Trang Quynh defeats Bà Chúa Liễu.

When Quynh went to take the official examination at primary level, he stopped at the shrine and made a wish and a vow to help him pass the examination. If he succeeded, he would come back to fulfil the vow.

Finally, he passed the test and began to think of his vow. He bought one cow and one baby cow and brought them to the shrine. He said, "Holiness, please accept my offering, This is the cow I promised but I would ask for the baby cow to be cooked to feed the villagers.

Quynh placed the cow on a table and he took the baby cow back home. The cow tried to follow him and the baby cow. This caused the table to collapse. Quynh laughed and walked back to the shrine. He said, "The holy one must have realized that I am a poor man. You have returned the cow to me. If you don't want it, I will take it back. I've never met such a generous divinity as you. I will always remember your kindness." Quynh was very happy and brought both cows back home.

(Nguyễn Trường 2004: 26-28)

The trick that Quynh used to tease the mother goddess who protected the holy shrine shows his cleverness and understanding of motherly instincts. He knew that he would not lose both cows to the mother goddess. The holy shrine is likewise tricked again in the story of the Ba Bor ceremony:

Once Quynh tricked the holy shrine. The holy goddess was angry but could not do anything. The goddess inflicted illness on the members of Quynh's family. Quynh then had to go to the shrine and make an apology. "I admit that I made a mistake. Please punish me not my family. They have nothing to do with what I did. Please forgive them. I will bring three cows (pronounced as Ba Bò in Vietnamese) for you. This time I will leave them outside the shrine. They will not disturb you like they did last time. Please! Holiness"

The mother goddess listened to Quynh and was glad. She thought of the three cows that she would get from Quynh. Then she lifted the punishment on Quynh's family. When Quynh's family had 
recovered from the illness, Quynh went back to the shrine but he did not bring anything with him. He told the holy one, "You forgave my family and I will present $\mathrm{Ba}$ Bò to you as I promised." Then, he went outside the shrine and started to creep around it three times (In Vietnamese $\mathrm{Ba}$ Bò also means creeping three times). When he had finished creeping, he stood up and swept the dust from his hands. He told the shrine's holy, "You must be satisfied now because I have already given you Ba Bò."

(Nguyễn Trường 2004: 31-32)

The above excerpt shows Quynh playing with the word "Ba Bor" in Vietnamese. It contains two meanings: three cows and a three-round creep. From both stories, it can be observed that Quynh teases and ridicules traditional belief. This is not to suggest that he has no respect for the shrine but he does not want people to give any gifts to the holy shrine since those gifts will belong to the landlords or those who own the land where the shrine is situated. In the series, a similar idea is also found in the story 'Eating two eggs to fulfil the vow given to the village Holy.'

\section{Trang Quynh and the King}

It is speculated that the King in the Trang Quynh series may refer to a king of the later Le dynasty ${ }^{8}$. There are many times

\footnotetext{
${ }^{8}$ The Le Dynasty ruled Vietnam at two periods. The former Le is the period between the years 1428 and 1789, starting from Le Thai To (or Le Loi). The later Le period is the period between 1533 and 1789 and gained support from Trinh lords who were very powerful in this period.
}

when the King loses face because of Quynh's tricks. Like the mother goddess Ba Chua Lieu, the King can do nothing and yields to Quynh as is demonstrated in the story 'Stealing King's cat':

Quynh noticed that the King's favourite cat had a golden chain around its neck and was provided with good food. Its food was as good as that served to the lords. The cat had steamed rice mixed with pork or fish at each meal. The cat's life was much better than that of the ordinary people. Quynh stole the cat from the palace. He fed the cat long enough to make it get used to him. On one occasion Quynh gave it rice with fish bone to the cat. Other villagers' cats also received this kind of food. In the beginning, the King's cat would not eat rice with fish bone. It waited for rice with pork or fish as it had once eaten in the palace. However, Quynh hit the cat when it got near the dish with meat and it soon learned that it could not eat meat and started eating fish bone. When Quynh was satisfied with the cat's training, he informed the King that he had found his lost cat at home. The King ordered Quynh to bring the cat to the palace. The King recognized the cat but Quynh said, "There are many cats like this in the country. They can be differentiated by their behaviour. The King's cat must have got used to good meals but villagers' cats will eat anything given to them. We need proof." The King agreed and ordered two dishes. The cat walked straight away to the dish with rice and fishbone. Quynh 
laughed and said, "This is a villagers' cat." Then, Quynh brought it back to his place.

(Nguyễn Trường 2004: 92-93)

Quynh did not enjoy making the King lose face but he tried to convey to the King the hardships and poverty of the people that the King might overlook. As opposed to the King's cat living a luxurious life, the villagers did not have enough to eat and resided in poor conditions. There are many chapters in the Trang Quynh tale series relating to Quynh satirizing the King and causing the King to lose face, such as, 'Male goat is pregnant,' 'Diamond,' 'Peaches of longevity,' 'Kings sleep during the day time,' 'Unprecedented dish: stone sprout stew,' 'The cabbage offered to the Seigneur' and 'The Doctor perished, the Seigneur died,' which is the final chapter in the series.

\section{Trang Quynh and the Lords}

There are two groups of lords that oppose Quynh. These two groups consist of the local lords (the Trinh family) and Chinese lords. The Trinh family supports the Le kings. They are powerful and take advantage of the people. Quynh reveals his criticism of the local lords who exploit the poor people in the story 'Annoying the lord':

One of the lords wanted Quynh, a well known scholar, to praise him with good words. Quynh pretended to look for kind words in books and then pondered these words for a while. Then he wrote down the word "thiền đức" (a man with kindness). The lord took the sign with this word back home and displayed it to the people. The lord framed it and then hung it on the wall.

Many days passed and the lord was called the "đực thiến" lord (eunuch) and this made him angry. But he was instructed, "You have a new sign hanging in front of your house, don't you? The word 'thiền đức' means kindness and $\mathrm{a}$ good man but if it is switched to "đực thiến," it will refer to a "eunuch." The lord felt embarrassed and immediately told his servants to take the sign down and hide it.

(Nguyễn Trường 2004: 52)

Making lords or high class people feel ashamed and lose face is another main issue in the series of Trang Quynh's trickster tales, especially in reference to the Trinh lord family, who lived a luxurious life. In the palace, lords and mandarins were divided into many groups, but they all focused on taking advantage of the people. They competed to be powerful. The eunuch group and King's favourite group were the most powerful. The administrative system was unstable and the honest lords were reduced in number. This was the main cause of the political crisis in the nation. The characteristics of the eunuch are openly ridiculed in the story 'Cock fighting': The story tells of how Quynh accepted the eunuch's invitation to a cock fight (Quynh's rooster was the winner in a cock fighting contest with the Chinese lords). However, Quynh did not want to pursue the cock fight with the group of eunuchs but instead wanted to teach them a lesson. Therefore, he brought another rooster instead of the winning one. The eunuch's cock finally won the fight. Quynh said, "This cock lost because it was castrated and this is the lesson of the 
defeat. It should be killed without sympathy." This statement can be seen as an attack on the eunuch group who wielded power in the royal court but who did nothing on behalf of the people and nation.

As for the Chinese lords, they are mentioned in many stories of the Trang Quynh series. In the long history of Vietnam's colonization by China and the significant influence of the Chinese, language and culture are often invoked. Quynh is therefore presented as a representative of the Vietnamese people and Vietnam as a country that can prevail over Chinese lords and China. In the story of Trang Quynh, both the Chinese lords in Vietnam and in China have to accept Quynh's cleverness. For example, there is the story of Quynh, as a diplomat, going to China to develop the relationship between China and Vietnam. The Chinese officials want to test Quynh's cleverness. They point at one part of a wooden stick and ask Quynh to identify whether it is made from the wood from bottom or top of the tree. Quynh says that he will offer an answer the next day. Quynh's servant sneaks out to put buffalo dung on the stick. Then he says to the referee, "Why did you bring that dirty stick to me! You should have washed it first." When the stick floats on water, the top part floats and the bottom part sinks. Quynh then knows the answer. Everyone admires his wisdom. (Nguyễn Trường 2004: 66-67).

The Chinese lords are characterized as supercilious, as shown in the stories of 'Drawing competition,' 'Buffalo fighting,' 'One method only,' 'Beautiful poetry,' and 'Guests after the host,' They are always characterized as intellectually inferior to Quynh. The triumph of Quynh over the Chinese lords brought pride to the nation through the suggestion that one could win over a mighty counterpart like China. For example, in the chapter on 'Buffalo fighting,' Quynh claps and says "We won over China, we won over China brothers and sisters." (Nguyễn Trường 2004: 105107). He never hesitates to show that he is proud to be Vietnamese. As he says to the Chinese lords in the story 'Beautiful Poetry,' "I am not a good writer. There are many smart people in my country. Every family in Vietnam has an uneducated man like me, one in every two families." (Nguyễn Trường 2004: 108-111). Here, Quynh speaks slowly and emphasizes the word "uneducated." Even the King has to applaud him for winning the poetry writing competition over the Chinese lords.

\section{Trang Quynh and the rich}

The group of rich people had higher status in the village because of their wealth and prosperity. However, their status could not be compared with high ranking officials. As illustrated in the story 'Mr. This, Mrs. That':

In the village where Quynh lived, the village head's sons wants to be famous and get respect (Ông no bà kia) like Quynh. Therefore they come to ask for Quynh's assistance. When Quynh comes back from the capital city, he calls them to his house and tells them, "Now it is your opportunity if you want to be distinguished people. You have to believe me and do whatever I tell you! You understand?" They are glad and accept immediately. Quynh continues, "You should pack your belongings and go with me. Tomorrow we will go to the 
capital city." They go home and dream that they will get honour and fame in the near future. One of them sees his wife standing in the house when he arrives home so he shouts to her, "Prepare yourself to be a master's lady. We will have luck." The wife asks with curiosity, "When will you be distinguished? Why do you look so happy?" The husband answers, "Go and pack. Tomorrow I will go to the capital city very early."

After packing, everyone goes back to Quynh's house. They have drunk so much that they begin to become unconscious. In the middle of the night, Quynh orders his servants take those men back to their family. Their faces are covered so that they can not be recognized. At home, their wives are asleep when their husbands arrive.

Next day, the wives lift the blankets and find that the men sleeping next to them are not their husband. They are all speechless. The husbands are embarrassed and go back to their own homes in hurry. Soon afterwards, they realize the meaning of "Ông nọ bà kia."

(Nguyễn Trường 2004: 32-34)

Again, Trang Quynh's trick is to play with the "Ông no bà kia" which has two meanings: being distinguished and being with the husband or wife of other people. This excerpt reflects the social situations in Vietnam at a time when bribery and corruption were widely practised, even in official examinations. A high position could also be bought for money.

The conflict between Quynh and his antagonists can be explained by Quynh's sympathy for the people. The story of Quynh, as a hero in Vietnamese folklore, shows the anger, fear and concern of the lower class in society. Throughout the series of Trang Quynh, the protagonist openly demonstrates his disdain for the rich, local mandarins, Chinese lords and even the king and holy shrines. This disdain derives from the exploitation and manipulation of the people. The privileged lived a luxurious life whereas the peasants have to endure hardship, poverty and even famine.

\section{Conclusion}

Trickster tales present the main character as wise and witty. The main character overcomes problems though wittiness, cleverness and intelligence and he or she can win in any situation by using tricks, mainly through playing on words. The trick can make enemies lose face, be injured or even die. In the world of tales, anything can happen and underdogs can also win.

The main purpose of trickster tales, including the story of Trang Quynh, is to entertain the listener. Criticism of social regulation can be subtly shown in the stories. In real life, it may be impossible for ordinary people to openly criticize the upper class but the writer, the narrator and the listeners to trickster tales help create a world where they can witness the loss and defeat of the people's antagonists.

The Trickster Tales of Trang Quynh aim to release the pressure of an unjust society constricted by otherwise impenetrable 
social regulations. While people feel uncomfortable and oppressed within these social rules, Quynh is especially enabled to project satires on to the high class, such as the nobility, government officials and Chinese rulers. All these literal actions may not be enacted in real life due to strict social obligations. Yet the trickster tales reveal and clarify the conflict between the common people and the groups that comprise the nobility in Vietnamese society. The trickster tales always entertain listeners, especially those of the lower class. They are not merely the products of the imagination of a human "being," but are also tales that portray a social reality, a way of life embedded within local traditions. These tales can reflect culture, a way of life, customs, traditions and the socio-cultural context of a particular time. They are an archive of human life and society. The historical context, thoughts and beliefs demonstrated in these tales are therefore vital for an understanding of the people that comprised a nation of the past.

\section{References}

Dinh Gia Khanh. 2003. Van hoc dan gian Viet Nam. Nam Dinh: Giao duc.

Hữu Ngọc. 1998. Sketches For a Portrait of Vietnamese Culture. Hanoi: Thế Giới Publishers.

Nathalang, Siraporn. 2005. Folklore Theories: Methodology in the Analysis of Folktales. Bangkok: Chulalongkorn University Press.

Nathalang, Siraporn. 1994. Folktales and Folkplays: A study of Folkore in the Thai Society Context. (ในท้องถิ่นมีนิทาน และการละเล่น) Bangkok: Matichon.
Nimmanahaeminda, Prakong. 2002. The study of Folktales. Bangkok:

Chulalongkorn University Press.

Ngưyễn Đức Hiền. 2003. Nguyễn Quỳnh Trạng Quỳnh Truyện Trạng Quỳnh. Đà Nẵng ; NXB Giáo Dục.

Nguyễn Trường. 2004. Truyện cười dân gian Việt Nam Trạng Cười. Thanh Niên ; NXB Thanh Niên.

Manirat, Phongphan. 1986. Anthropology and The Study of Folklore. (Manutsayawitthaya Kap Kansueksa Khatichaoban) Bangkok: Thammasat University Press.

Vejchasartra, Kanyarat. 1998. Srithanonchai in Southeast Asia. (Si Thanon Chai Nai Usakhane) Bangkok: Thammasat University Press. 